\title{
The Use of Basins for Reducing Downstream Flooding (A Case Study of Flood Control at Ganggang Sub-Watershed of Bojonegoro Regency)
}

\author{
$1^{\text {st }}$ Windarti Eko Rahayu, \\ Civil Engineering Department \\ Faculty of Engineering \\ Universitas Negeri Malang \\ Jl. No 5, Malang 65145, Indonesia \\ windartieko17@gmail.com \\ $4^{\text {th }}$ Nugroho Suryoputro, \\ Civil Engineering Department \\ Faculty of Engineering \\ Universitas Negeri Malang \\ J1. No 5, Malang 65145, Indonesia \\ nugrohosuryoputro@gmail.com
}

\author{
$2^{\text {nd }}$ Mujiyono, \\ Civil Engineering Department \\ Faculty of Engineering \\ Universitas Negeri Malang \\ J1. No 5, Malang 65145, Indonesia \\ mujiono.sy artec@ gmail.com
}

\author{
$3^{\text {rd }}$ Anie Yulisty orini, \\ Civil Engineering Department \\ Faculty of Engineering \\ Universitas Negeri Malang \\ Jl. No 5, Malang 65145, Indonesia \\ anie.yulisty orini.ft@um.ac.id, \\ $5^{\text {th }}$ Gilang Idfi \\ Civil Engineering Department \\ Faculty of Engineering \\ Universitas Negeri Malang \\ Jl. No 5, Malang 65145, Indonesia
}

\begin{abstract}
This study was aimed to investigate (1) the use of basins at Ganggang sub-watershed as retarding basins, (2) the storage volume required by the inundation at the downstream of Ganggang subwatershed, and (3) the capacity volume of the area at Ganggang sub-watershed. The method used in this study were (1) producing the topographic map of Ganggang sub-watershed by using Google Earth, Surfer and ArcMap 10.4.1, (2) calculating the capacity volume of retarding basin according to inundation parameter and sensing of the basin topographic using ArcMap 10.4.1, (3) measuring the area of the basin using ArcMap 10.4.1, (4) calculating the capacity volume of the basin. This study produced several outputs such as topographic maps of Ganggang subwatershed, a site-plan of the retarding basin location, and a design volume of the retarding basin capacity.
\end{abstract}

Keywords: Flood, Ganggang sub-watershed, retarding basin

\section{I.INTRODUCTION}

Indonesia is a tropical country which has heavy rainfall. The high rainfall intensity causes of flooding in many areas of Indonesia including Bojonegoro Regency. This regency is located in the plain area which surrounded by limestone mountain plateau and Bengawan Solo River also across that regency. This topography leads many areas in Bojonegoro prone to flooding [1]. Ngulanan Village is one of the flood-prone areas in the sub-district of Dander. The flood caused widespread destruction which damaged 85 houses and 65 of rice field blocks [3]. According to the information from the local people, the flood inundated of approximately 200 ha of rice fields and
50 ha of settlements in a week in with the water reach up to 1.75 meters in depth. This disaster was influenced by the flooding of the Ganggang subwatershed in which the streamflow in the Ganggang sub-watershed was delayed to reach the outlet because of the backwater of the Bengawan Solo River.

Previous research revealed that Ganggang sub-watershed has a slope of $0.69 \%$ and it is classified as flat or very flat relief class [2]. Bermana and his co-worker also mentioned that flat slopes usually consist of basins. The slope of the topography at a watershed will result in lower runoff rates than that with steep of the topography slope, and therefore generating in several inundated basins [12]. The method of flood control which use several basins or swamps to serve as a retention pond or retarding basin has been explained in detail by Kodoatie[7] and this method is useful to be applied to solve flooding problem in Ganggang subwatershed. The basin type at the Ganggang subwatershed could be identified by using the Geographic Information System (GIS) and it was visualised in ArcMap 10.4.1 application,

Moreover, this research was aimed to investigate the use of basins at the Ganggang sub-watershed to temporarily retain the flood discharge, and therefore the flood peak discharge can be delayed.

\section{LITERATURE REVIEW}

A retention pond is a rainwater pond/reservoir for temporary storage which serves to delay the flood peaks in the river [4]. It is a method 
of the flood control that use a basin or swamp as a temporary rainwater catchment system [7].

The basin uses as a catchment ponds should be selected based on several approaches as described by Fedorov et al. (2016). The considerations that they use are (1) the envelope topography forms which has a basin; (2) the structure of the drainage basin is characterised by an orderly contour line; (3) the influence of the basin on the natural environment and economic activity in the basin area should be considered; (4) the landscape system of a basin is an optimal area for environmental monitoring; and (5) the use of simulation of various processes and objects in that environment using GIS serves to optimise natural resource management [5].

In the selection of the retention pond location, it is required to calculate the storage volume to determine the area of the basin. Based on the Guideline of the Construction of Retention Pond and Polder that published by Directorate General of Human Settlements of the Office of Public Works (2010), the location of the retention pond should be considered on some inundation parameters, i.e. inundation height, area, and duration [4]. In the flood control, it is necessary to design a storage volume based on Basin Storage Capacity (BSC) in the upstream area since flood runoff depends on the upstream area. Usutani \& Nakatsugawa (2011) proposed two methods for estimating the BSC, namely (1) the calculation of runoff volume percentage and (2) the calculation based on the water level in a flood event [11].

\section{METHOD}

The research was located at Ganggang subwatershed with the coordinates of longitude $111^{\circ} 821^{\prime}$ $-11^{\circ} 585^{\prime}$ East and latitude $7^{\circ} 156^{\prime}-7^{\circ} 171^{\prime}$ South. It is located in Dander Sub-District of Bojonegoro Regency. Ganggang sub-watershed is part of the downstream of Bengawan Solo watershed. Its total area is $77.35 \mathrm{Km} 2$ and consists of 12 rivers with a main river length of $26.09 \mathrm{~km}$.

This research required severaldata such as a map of the Ganggang sub-watershed, topographic map, land use map, and inundation parameters. The instruments employed in this study were Google Earth, Surfer and ArcMap 10.4.1 applications.

This study was conducted through the following systematic stages.

1. Creating a topographic map based on Google Earth satellite, then it converted into contour map using Surfer program

2. Calculating the designed storage volume of basin

3. Deciding the basin location which has an envelope basin shape and it is based on the topographic map that created using ArcMap 10.4.1 application. The selected location of the basin should not disturb the existing of a residential area.
4. Measuring the inundation area of each basin in different elevation level

5. Calculating the storage capacity of the basin

\section{RESULTS AND DISCUSSION}

\subsection{Topography of Ganggangs sub-watershed} and its storage volume

The Surfer app was used to convert the satellite maps from Google Earth to topographic maps as shown in the following figures.

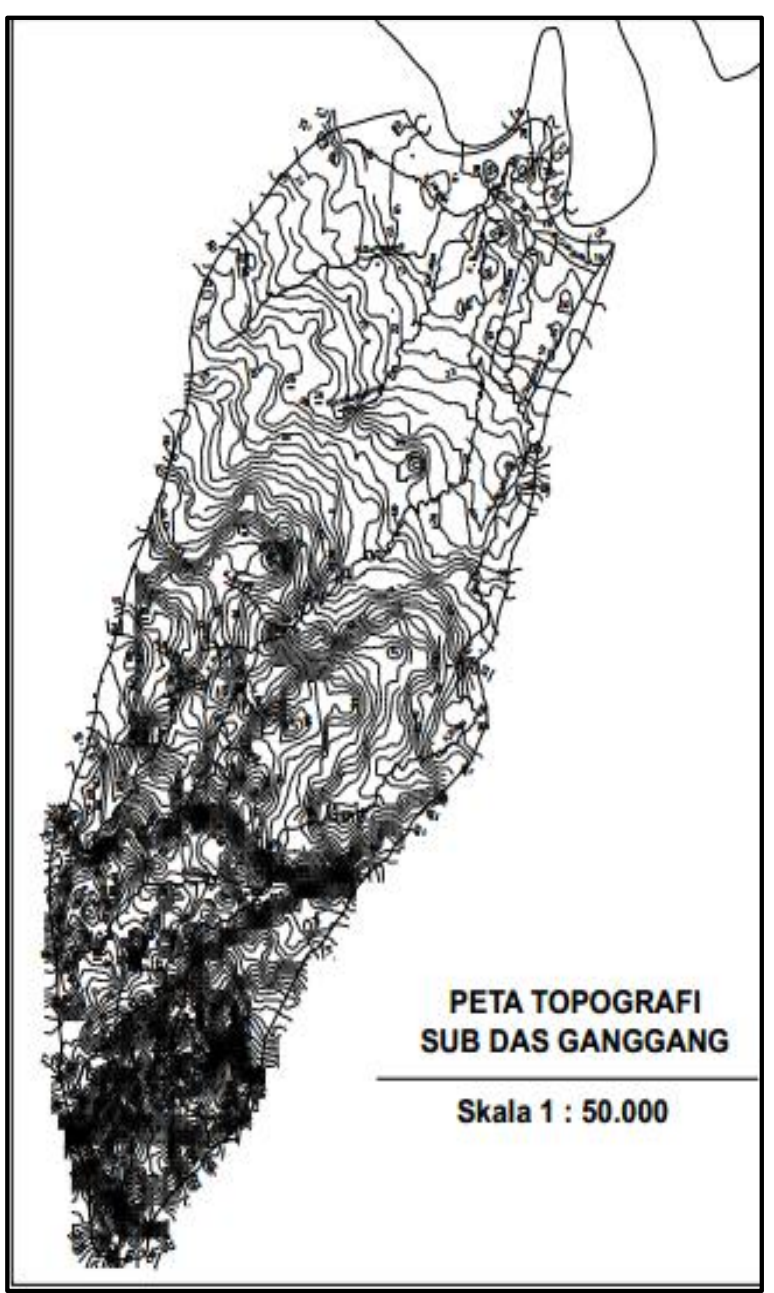

Fig 1 Topography of Ganggang sub-watershed 


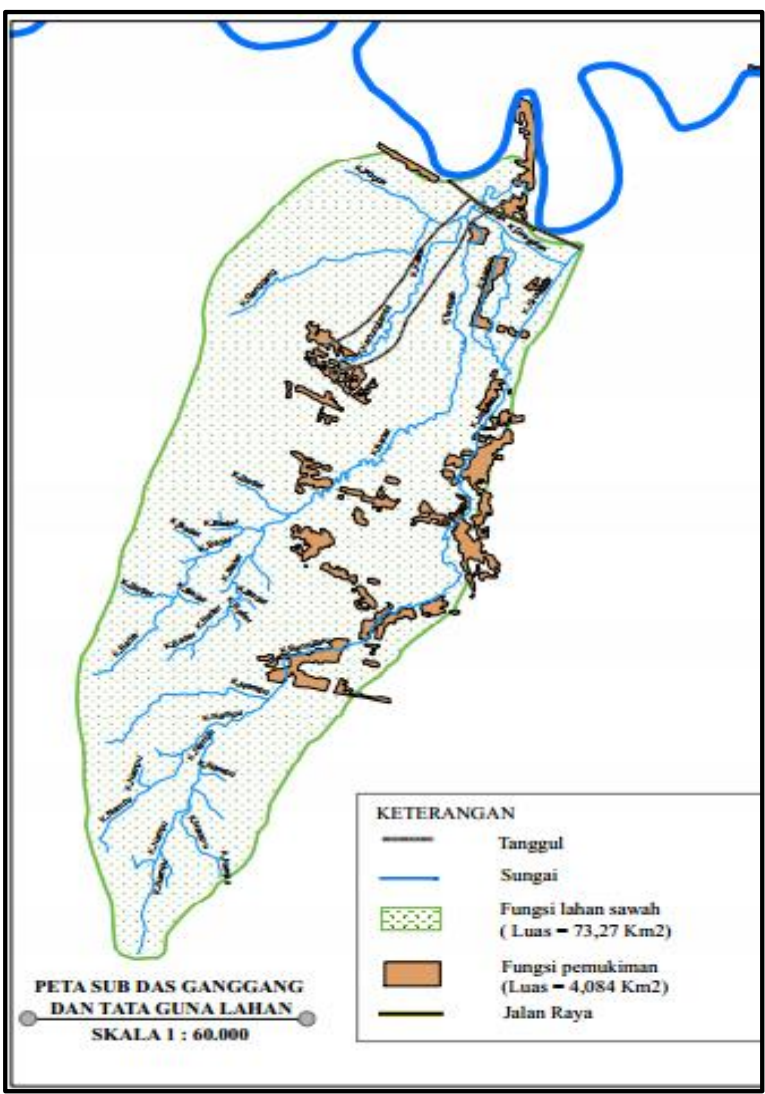

Fig 2 Land use map at Ganggang sub-watershed

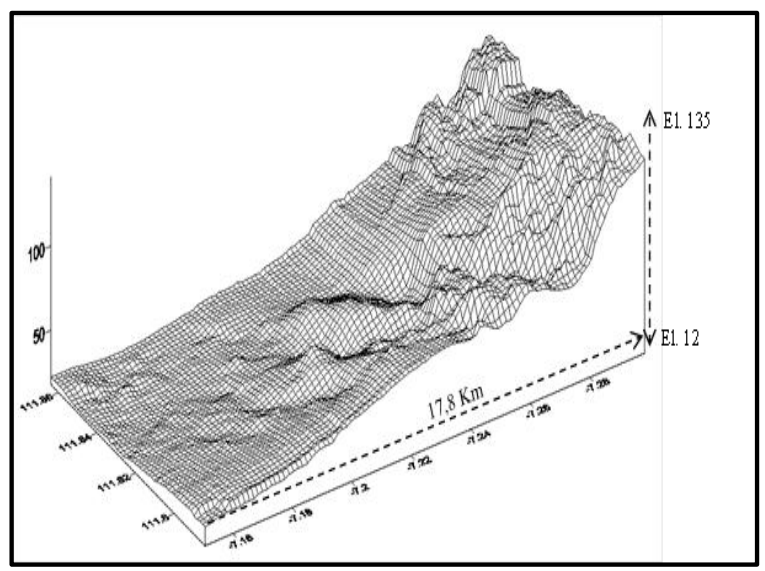

Fig 3 3D Surfaces

The images from Google Earth shows that Ganggang sub-watershed is at an elevation of 12-135 $\mathrm{m}$ above sea level and $17.8 \mathrm{~km}$ in length. Bermana (2006) categorised that elevation into a flat or flat slope [2]. As shown in Figure I, there are some basins in Ganggang sub-watershed. The particular basins were selected according to the contour shape and they were not located in the residential area [5]. The three selected basins are illustrated in Figure 4.

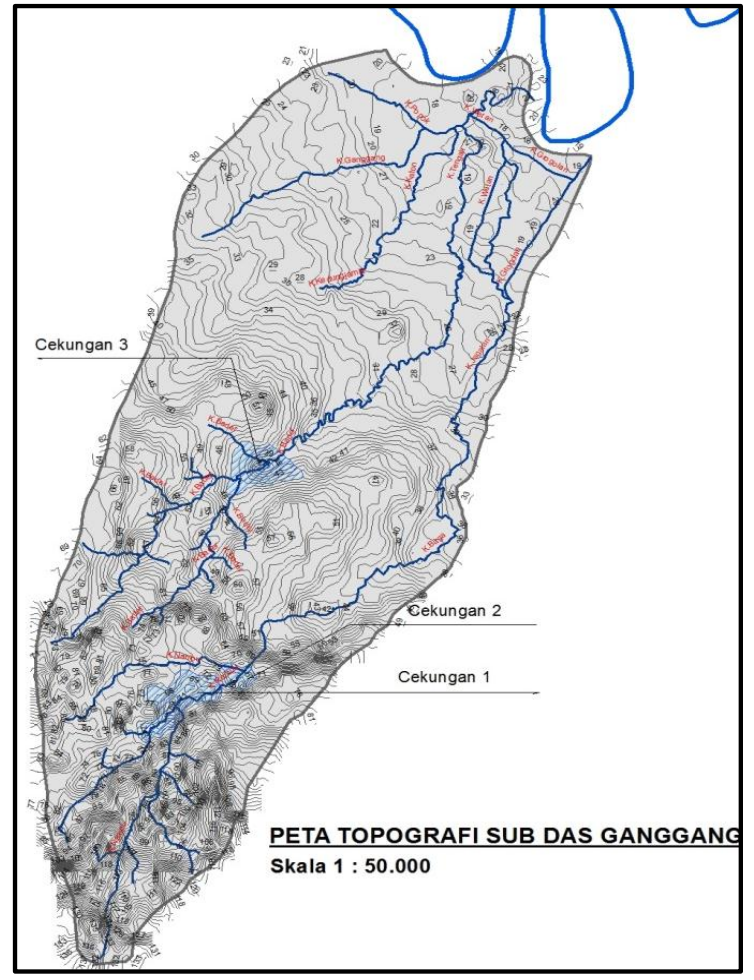

Fig 4 Topography of the selected basins

\subsection{Storage Volume}

In this study, the storage volume was planned based on (1) the percentage of runoff discharge; (2) the inundation parameters, and (3) the height of water level during flood [5][4][11]. Data obtained from this study were the inundation parameters in the downstream of Ganggang subwatershed, and therefore they used as the reference of the required storage volume. The residents informed that approximately 200 ha of rice fields and 50 ha of settlements were inundated for seven days and up to a depth of $1.75 \mathrm{~m}$. Based on this information, the required temporary storage was estimated to be $\pm 4,375,000 \mathrm{~m} 3$.

The basin area at each level of elevation was measured using the ArcMap 10.4.1 in order to determine the required capacity volume of the catchment basin. The storage volume measurement of the first basin is shown in Table 1.

T ABLE 1 VOLUME OF ST ORAGE CAPACITY OF BASIN 1

\begin{tabular}{|c|c|c|c|c|}
\hline Elevation & $\mathrm{h}$ & $\begin{array}{c}\text { Storage } \\
\text { Area }\end{array}$ & $\begin{array}{c}\text { Storage } \\
\text { Volume }\end{array}$ & $\begin{array}{c}\text { Cumulative } \\
\text { Volume }\end{array}$ \\
\hline $\mathrm{m}$ & $\mathrm{m}$ & $\mathrm{m}^{2}$ & $\mathrm{~m}^{3}$ & $\mathrm{~m}^{3}$ \\
\hline 67 & 1 & $3,625.65$ & 0 & 0 \\
\hline 68 & 1 & $31,164.31$ & $17,394.98$ & 17,395 \\
\hline 69 & 1 & $67,597.45$ & $49,380.88$ & 66,776 \\
\hline 70 & 1 & $163,957.10$ & $115,777.28$ & $182,553.14$ \\
\hline 71 & 1 & $296,128.00$ & $230,042.55$ & $412,595.69$ \\
\hline 72 & 1 & $478,157.50$ & $387,142.75$ & $799,738.44$ \\
\hline 73 & 1 & $703,760.30$ & $590,958.90$ & $1,390,697.34$ \\
\hline 74 & 1 & $886,153.20$ & $794,956.75$ & $2,185,654.09$ \\
\hline
\end{tabular}


The storage volume needed to store the inundation flow at the downstream of Ganggang subwatershed was $\pm 4,375,000 \mathrm{~m} 3$, while the volume of the storage capacity of basin area 1 was 2,185,654.09 $\mathrm{m} 3$, meaning that the capacity of the first basin is not enough to store the inundation. Another viable alternative to solve this problem is the use of multiple basins within a catchment area, i.e. utilising some basins to make temporary storage [10]. This method can be used as a backup storage area to retain the flood by applying multi reservoir approach [6]. Furthermore, the measurement of the area of basin 2 and 3 was done using the same method and the results are presented in Table 2 and 3.

TABLE 2 VOLUMEOF ST ORAGE CAPACITY OF BASIN 2

\begin{tabular}{|c|c|c|c|c|}
\hline Elevation & $\mathrm{h}$ & $\begin{array}{c}\text { Storage } \\
\text { Area }\end{array}$ & $\begin{array}{c}\text { Storage } \\
\text { Volume }\end{array}$ & $\begin{array}{c}\text { Cumulative } \\
\text { Volume }\end{array}$ \\
\hline $\mathrm{m}$ & $\mathrm{m}$ & $\mathrm{m}^{2}$ & $\mathrm{~m}^{3}$ & $\mathrm{~m}^{3}$ \\
\hline 65 & 1 & $2,237.00$ & 0 & 0 \\
\hline 66 & 1 & $11,135.51$ & $6,686.26$ & $6,686.26$ \\
\hline 67 & 1 & $31,767.05$ & $21,451.28$ & $28,137.54$ \\
\hline 68 & 1 & $92,936.09$ & $62,351.57$ & $90,489.11$ \\
\hline 69 & 1 & $162,942.70$ & $127,939.40$ & $218,428.50$ \\
\hline 70 & 1 & $213,038.00$ & $188,161.85$ & $406,590.35$ \\
\hline
\end{tabular}

TABLE 3 VOLUMEOF ST ORAGE CAPACITY OF BASIN 3

\begin{tabular}{|c|c|c|c|r|}
\hline Elevation & $\mathrm{h}$ & $\begin{array}{c}\text { Storage } \\
\text { Area }\end{array}$ & $\begin{array}{c}\text { Storage } \\
\text { Volume }\end{array}$ & $\begin{array}{c}\text { Cumulative } \\
\text { Volume }\end{array}$ \\
\hline $\mathrm{m}$ & $\mathrm{m}$ & $\mathrm{m}^{2}$ & $\mathrm{~m}^{3}$ & \multicolumn{1}{c|}{$\mathrm{m}^{3}$} \\
\hline 37 & 1 & $13,756.85$ & 0 & 0 \\
\hline 38 & 1 & $42,847.48$ & $28,302.17$ & 28,302 \\
\hline 39 & 1 & $116,360.64$ & $79,604.06$ & 107,906 \\
\hline 40 & 1 & $178,711.02$ & $147,535.83$ & $255,442.06$ \\
\hline 41 & 1 & $255,540.00$ & $217,125.51$ & $472,567.57$ \\
\hline 42 & 1 & $344,949.46$ & $300,244.73$ & $772,812.30$ \\
\hline 43 & 1 & $481,496.65$ & $413,223.06$ & $1,186,035.35$ \\
\hline 44 & 1 & $743,721.55$ & $612,609.10$ & $1,798,644.45$ \\
\hline
\end{tabular}

The results showed that the total volume of the basin 1,2 and 3 was 4,390,888.89 $\mathrm{m} 3$ as described in Table 4. Since the volume of storage capacity is larger than the volume of inundation $(4,390,888.89 \mathrm{~m} 3>4,375,000 \mathrm{~m} 3)$, the three catchment basins at Ganggang sub-watershed could store the maximum inundation at the downstream of Ganggang sub-watershed.

TABLE 4 VOLUME OF STORAGE CAPACITY OF GANGGANG SUB-WATERSHED

\begin{tabular}{|l|r|c|}
\hline \multicolumn{1}{|c|}{ Retarding Basins } & \multicolumn{1}{c|}{$\begin{array}{c}\text { Storage } \\
\text { Volume }\end{array}$} & Unit \\
\hline Basin 1 & $2.185 .654,09$ & $\mathrm{~m}^{3}$ \\
\hline Basin 2 & $406.590,35$ & $\mathrm{~m}^{3}$ \\
\hline Basin 3 & $1.798 .644,45$ & $\mathrm{~m}^{3}$ \\
\hline Total Volume & $\mathbf{4 , 3 9 0 , 8 8 8 . 8 9}$ & $\mathbf{m}^{3}$ \\
\hline
\end{tabular}

According to Loucks and van Beek (2017) the inundation volume should not be higher than the storage capacity of basin [8] and the storage capacity has a relationship with its area [9]. This relationship is shown in Figure 5 to 7.

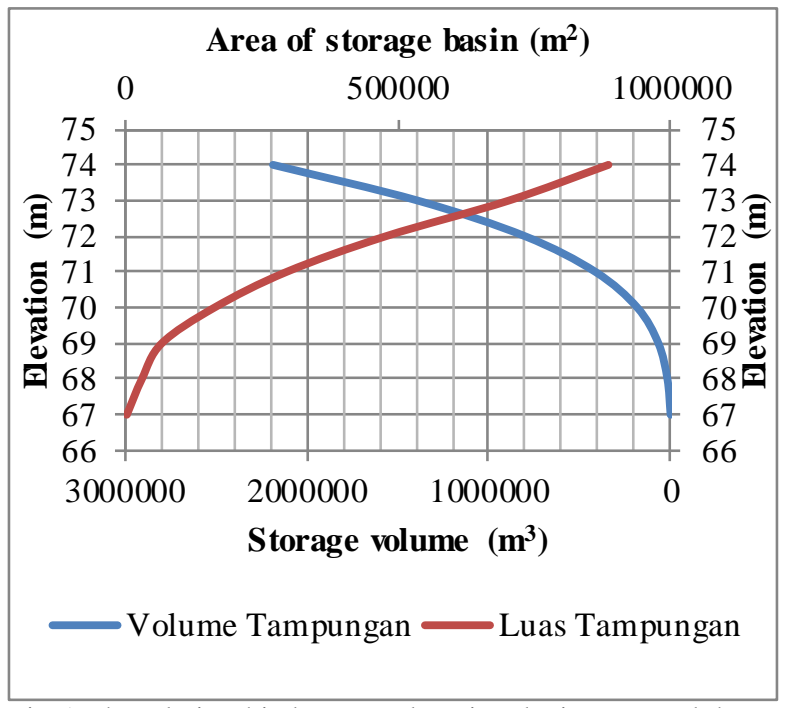

Fig 5 The relationship between elevation, basin area, and the storage capacity of basin 1

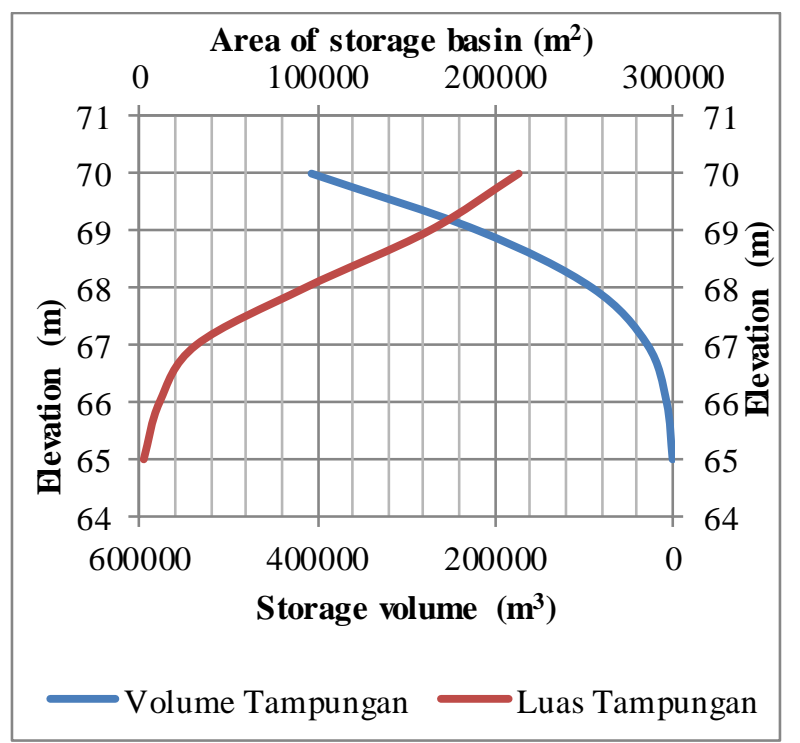

Fig 6 The relationship between elevation, basin area, and the storage capacity of basin 2 


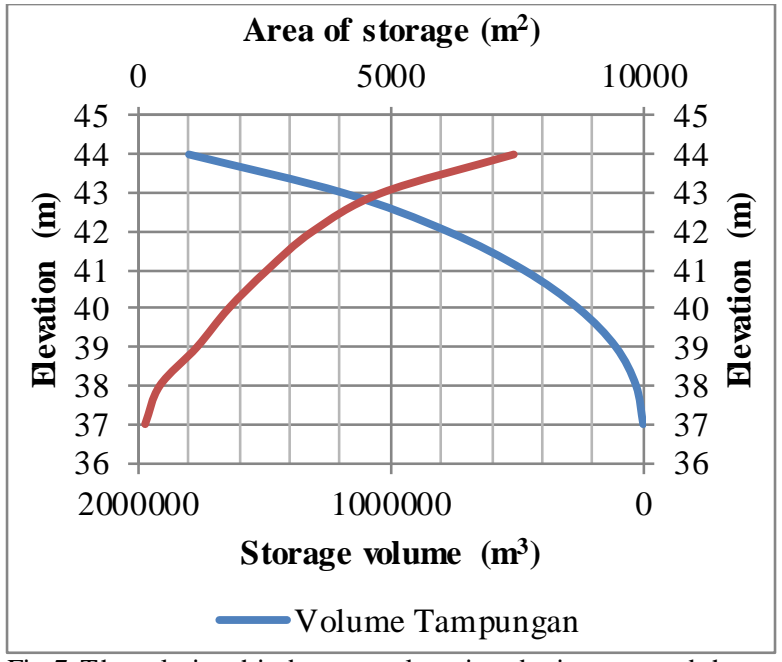

Fig 7 The relationship between elevation, basin area, and the storage capacity of basin 3

The relationship between elevation, basin area, and the storage capacity of basin curves explained that each difference elevation shows a difference basin surface area. The Figure 5 to 7 also show the relationship between elevation level and basin surface area that present the storage capacity of the basin, and therefore these curves can be used to produce spillway design to be applied as a retarding basin.

\subsection{Retarding Basin Considerations}

According to the map which presented using ArcMap 10.4.1, the retarding basin would be located in the area shown in Figure 8 with a number of following considerations:

1. The basins are located in the area with orderly contour lines [4].

2. The location of the basins does not affect economic activity due to its distance to the residential areas (see Figure 2) [4][5][7 ]

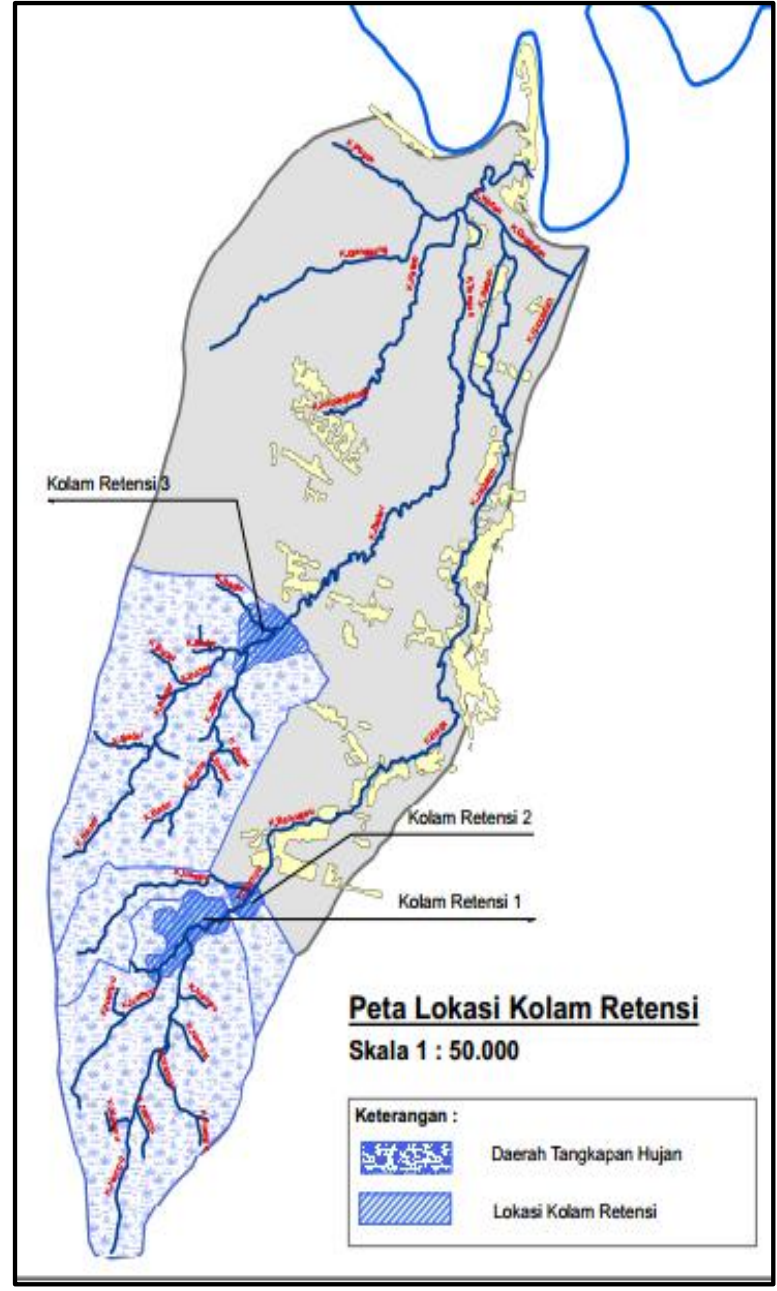

Fig 8 Location of the retarding basins

\section{CONCLUSION}

In order to manage the flooding at Ganggang subwatershed, there is three requirements of the retarding basin which have a total storage capacity of $4,390,888.89 \mathrm{~m} 3$ should be built in Dander of Bojonegoro regency. These basins can retain the water from the inundation flow of about 4,375,000 $\mathrm{m} 3$ at Ganggang sub-watershed and $15,889 \mathrm{~m} 3$ of a free space still available to hold the water during the heavy rain

\section{REFERENCES}

[1] Aziz, M. L. (2012).Pemetaan Tingkat Kerentanan dan Tingkat Bahaya Banjir Daerah Aliran Sungai (DAS) Bengawan Solo Bagian Tengah di Kabupaten Bojonegoro. Universtitas Negeri Yogyakarta

[2] Bermana, I. (2006). Klasifikasi Geomorfologi Untuk Pemetaan Geologi yang Telah Dibakukan. Bulletin of Scientific Contribution, 4, 161-173.

[3] Cahyanto, A. D. (2013). Kajian Kondisi Sosial, Ekonomi, Lingkungan Terbangun dan Program Pemerintah Terhadap Banjir Bengawan Solo Di Desa Ngablak Kecamatan Dander Kabupaten Bojonegoro.

[4] Direktorat Jenderal Cipta Karya Departemen Pekerjaan Umum. (2010). Buku Panduan Tata Cara Pembuatan Kolam Retensi dan Polder dengan Saluran-Saluran Utama (Vol. 5).

[5] Fedorov, M., Badenko, V., Maslikov, V., \& Chusov, A. 
(2016). Site Selection for Flood Detention Basins with Minimum Environmental Impact. Procedia Engineering, 165 , $1629-1636$

https://doi.org/10.1016/j.proeng.2016.11.903

[6] Fu, X., Li, A. Q., \& Wang, H. (2014). Allocation of Flood Control Capacity for a Multireservoir System Located in the Yangtze River Basin. Water Resources Management, 28(13), 4823-4834.https://doi.org/10.1007/s11269-0140778-9

[7] Kodoatie, R. J. (2015). Rekayasa dan Manajemen Banjir Kota. Yogyakarta: ANDI OFFSET

[8] Loucks, D. P., \& van Beek, E. (2017). Water Resource Systems Planning and Management. https://doi.org/10.1007/978-3-319-44234-1
[9] Rodrigues, L. N., Sano, E. E., Steenhuis, T. S., \& Passo, D. P. (2012). Estimation of small reservoir storage capacities with remote sensing in the Brazilian Savannah region. Water Resources Management, 26(4), 873-882. https://doi.org/10.1007/s11269-011-9941-8

[10] State Govermment Victoria, \& Melbourne Water. (n.d.). Retarding Basin Design and Assessment Guideline.

[11] Usutani, T.,\& Nakatsugawa, M. (2011). Utilization of the St orage Capacity of a Basin. Journal of Japan Society of Civil Engineers, 535-540.

[12] Verrina, G. P., \& Anugrah, D. D. (2013). Analisa Runoff Pada Sub Das Lematang Hulu. Jurnal Teknik Sipil Dan Lingkungan, 1(1). 